\title{
PHYTOPLANKTON COMPOSITION AND ITS RELATION TO PEARL OYSTER AQUACULTURE (Pinctada maxima) IN SEKOTONG, WEST NUSA TENGGARA
}

\author{
Fathurrahman $^{1}$, Aunurohim ${ }^{1}$, and Varian Fahmi ${ }^{2 *}$ \\ ${ }^{1}$ Jurusan Biologi, Institut Teknologi Sepuluh Nopember, Surabaya \\ ${ }^{2}$ Lembaga Ilmu Pengetahuan Indonesia (LIPI), Lombok \\ *E-mail: varian.fahmi@lipi.go.id; varian_fahmi@yahoo.com
}

\begin{abstract}
Pearl oyster aquaculture is one of the marine industries that is currently growing in West Nusa Tenggara. Pearl oyster (Pinctada maxima) is a common species of oyster that cultivated in West Nusa Tenggara waters. A suitable location is an important factor for the success of pearl aquaculture industry. It needs a good water quality and supported by appropriate physical parameters for other marine biotas. The aim of this research was to analize phytoplankton composition (biological parameter) and it correlation to the Sekotong water condition for pearl farming production. The result showed that the pearl farming location has good water condition according to physio-chemical parameter and water nutrients. All parameters were in suitable range for the growth and development of pearl oysters.
\end{abstract}

Keywords: pearl farming, phytoplankton, Pinctada maxima, West Nusta Tenggara

\begin{abstract}
ABSTRAK
Budidaya Mutiara Tiram merupakan salah satu industri kelautan yang sedang berkembang di Nusa Tenggara Barat. Mutiara Tiram (Pinctada maxima) adalah spesies umum tiram yang dibudidayakan di perairan Nusa Tenggara Barat. Lokasi budidaya yang cocok bagi tiram merupakan faktor penting bagi keberhasilan industri budidaya mutiara. Hal ini membutuhkan kualitas air yang baik dan didukung oleh parameter fisik yang sesuai untuk biota laut lainnya. Tujuan dari penelitian ini adalah untuk menganalisis komposisi fitoplankton (parameter biologi) dan korelasinya dengan kondisi air Sekotong untuk produksi budidaya mutiara. Hasil penelitian menunjukkan bahwa lokasi budidaya mutiara memiliki kondisi air yang baik sesuai dengan parameter fisika-kimia dan nutrisi air. Semua parameter berada pada kisaran yang cocok untuk pertumbuhan dan perkembangan Mutiara Tiram.
\end{abstract}

Kata kunci: tambak tiram, fitoplankton, Pinctada maxima, Nusa Tenggara Barat

\section{INTRODUCTION}

Indonesia has a lot of marine potential that can be developed. Pearl oyster farming is of the great potential that must be organize utilize. Pinctada maxima are one of the marine organisms that found in waters of Indonesia. One of the export commodities from Indonesia is pearl that produced from Pinctada maxima (Anggoro, 2004).

Lombok is located in West Nusa Tenggara that develops pearl farming. With production of $600 \mathrm{~kg}$ per year, pearl has become iconic in Lombok. The pearl quality is known worldwide. There are 36 pearl com- panies scattered in West Nusa Tenggara (Astuti and Hendra, 2009).

Location play key role for the success of pearl farming. Good location for pearl farming must met the standard including: water quality, nutrient, seed, infrastructure, safety and transportation (Agusta, 2012).

Pearl oyster belongs to the bivalve class from mollusc phylum. The main characteristic from this class is they have 2 shells, soft body with small foot, byssal gland and gills are paired. Pearl oyster can be found in tropic region and grow in clear water. Bivalves are an ideal marine organism to cultivate. These animals belong to the group of 
herbivores that do not require additional food because they feed phytoplankton that naturally occur. (Mathiessen, 2001; Haws, 2002; Powell et al., 2002, 2004; Fernandez et al., 2006). They reproduce by releasing sperm and eggs in water column. Less than 24 hours, the fertilized eggs will develop into trochepore larvae and swim freely in the water. The larvae will metamorph into juvenile and attach to the spat. The oyster can attach, migrate and reattach by using its by ssus (Haws, 2002).

The oyster eat plankton by filtering the surrounding water into filtering system and ingest small particle that contain organic matter (Dunphy et al., 2006). This mechanism was happen due to coordinated small cilia movement on gill surface. The particles larger than $10 \mu \mathrm{m}$ will expelled. The digestive system of oyster cannot break down cellulose matter.

As phytoplankton are the main food, the biochemistry composition play key role to determine the nutrition quality in phytoplankton and its function for bivalve. Biochemistry model are used to stimulate the growth and survival of bivalve larvae in various conditions (Powell et al., 2002, 2004). The model shows that the increased survival rate larvae bivalve associated with low protein and high levels of lipid and carbohydrate. This composition is very important during bivalve the an attachment (MartínezFernández and Southgate, 2007). The larval growth is influenced by the level of carbohydrate, lipid and protein contained in phytoplankton (Fernández and Salmon, 2004; Southgate, 2006).

The aim of this research was to analyse the phytoplankton composition and its relation to water quality in pearl farming (Pinctada maxima) in Sekotong.

\section{METHOD}

\subsection{Sampling Phytoplankton}

Samples were taken in 2 locations Sekotong, West Nusa Tenggara. The parame- ters that will be measured including: biological (phytoplanton), the chemical (nutrient) and physical (temperature, salinity).

Phytoplankton was taken by using 20 $\mu \mathrm{m}$ net tow. Samples were taken at the surface and depth. For surface sampling, the net plankton was towed $100 \mathrm{~m}$ horizontally. The water in the cod was transferred to $50 \mathrm{ml}$ vial. Van Dorn was used to take the sample in $7 \mathrm{~m}$ deep. The water sample that was taken was the same like surface sampling. All samples were preserved by adding $0,5 \mathrm{ml} / 50 \mathrm{ml}$ Lugol solution (Barus, 2004). Samples were taken to LIPI Mataram and ITS Surabaya for identification and documentation. Phytoplankton was identify according to Omura et al. (2012) and Horner (2002). The phytoplanktons were quantified using Sedgewick rafter. The density were counted using formula:

$$
K=\frac{n}{m} x \frac{s}{a} x \frac{l}{v}
$$

explanation: $\mathrm{K}=$ density (cells/L), $\mathrm{n}=$ number of counted cell in $\mathrm{m}, \mathrm{m}=$ number of drop, $\mathrm{s}=$ sample volume, $a=$ volume of sample, and $v=$ volume of filtered water $\left(\mathrm{m}^{3}\right)$

Ammonia, nitrate, nitrite and phosphate concentration were measured in KKP Lombok laboratory using Lambda XLS spectrophotometer.

\section{RESULT AND DISCUSSION}

\subsection{Phytoplankton Composition}

There were 23 species of phytoplankton found in Sekotong West Nusa Tenggara (Table 1). Bacillariophyceae, Dinophyceae and Dictyochophyceae are families among phytoplankton that were found. The highest density among them was Bacillariophyceae (more than 99\%).

Bacillariophyceae have wide range for its adaptation which may survive from environmental change. Most of phytoplankton in Bacillariophyceae class are euryhaline 
Table 1. Phytoplankton densities in Sekotong, West Nusa Tenggara, Indonesia.

\begin{tabular}{|c|c|c|c|c|c|}
\hline \multirow[b]{2}{*}{ Class } & \multirow[b]{2}{*}{ Genus } & \multicolumn{2}{|c|}{ Density (Cell/L) } & \multicolumn{2}{|c|}{ Percentage $(\%)$} \\
\hline & & $\begin{array}{c}\text { Location } \\
1\end{array}$ & $\begin{array}{c}\text { Location } \\
2\end{array}$ & $\begin{array}{c}\text { Location } \\
1\end{array}$ & $\begin{array}{c}\text { Location } \\
2\end{array}$ \\
\hline \multirow{17}{*}{ Bacillariophyceae } & Skeletonema & 814.713 & 484.010 & 83.3 & 83 \\
\hline & Chaetoceros & 79.872 & 29.620 & 8 & 3 \\
\hline & Bacteriastrum & 25.586 & 20.093 & 2.6 & 2 \\
\hline & Coscinodiscus & 246 & 410 & 0.03 & 0.04 \\
\hline & Eucampia & 164 & 82 & 0.01 & 0,008 \\
\hline & $\begin{array}{l}\text { Hemialus } \\
\text { hauckii }\end{array}$ & 82 & 82 & 0.008 & 0.008 \\
\hline & Guinardia & & 82 & & 0.008 \\
\hline & Navicula & 3.281 & 4.921 & 0.34 & 0.5 \\
\hline & Pseudonitzschia & 17.879 & 7.628 & 1.8 & 0.78 \\
\hline & Pleurosigma & 410 & 82 & 0.04 & 0.008 \\
\hline & Rhizosolenia & 4.511 & 4.347 & 0.46 & 0.4 \\
\hline & Thalassionema & 21.323 & 15.016 & 2.2 & 1.5 \\
\hline & Odontella & 164 & & 0.01 & \\
\hline & Thalassiosira & 7.874 & 11.153 & 0.8 & 1.1 \\
\hline & Entomoneis & 328 & 574 & 0.03 & 0.05 \\
\hline & Chylindrotheca & 411 & 3.034 & 0.04 & 0.3 \\
\hline & Detonula & & 656 & & 0.07 \\
\hline \multirow{4}{*}{ Dinophyceae } & Protoperidinium & 738 & 574 & 0.08 & 0.05 \\
\hline & Ceratium furca & 328 & 738 & 0.03 & 0.08 \\
\hline & Gonyaulax sp & $<1$ & & & \\
\hline & Pyrophacus & & 246 & & 0.03 \\
\hline Dictyochophyceae & Dictyocha & 164 & 82 & 0.01 & 0.008 \\
\hline
\end{tabular}

which can survive in salinity 5\%o-30\%o (Dwiponggo, 1976). They reproduce by means of vegetative cell division. The cells contain two part : the upper part (epitheca) and lower part (hypotheca). Epitheca will pairs with hypotheca to form a new cell. This ability makes phytoplankton abundant in nature, especially if supported by availability of nutrients. When the seawater rich of nutrients, the phytoplankton that belong to the diatom group can reproduce three times in 24 hours (Effendi, 2003). While the dinoflagellate group can only reproduce once in 24 hours with the same condition.

There were five species found in Sekotong (Bacillariophyceae) that its existence in quite abundant (more than $10^{4}$ cell/L),
Skeletonema, Chaetoceros, Bacteriastrum, Pseudonitzschia, Thalassionema and Thalassiosira sp. From two locations, Skeletonema have the highest density with average percentage up to $83 \%$. According to Veronica et al. (2014), there are three categories of phytoplankton abundance related to nutrient in water. The density of phytoplankton in less nutrient water is below $10^{4}$ cell/L, adequate nutrient is between $10^{4}-10^{7}$ cell/L and high nutrient is above $10^{7}$ cell/L. The condition where the density of phytoplankton is more than $10^{7}$ cell/L is called blooming (Efrizal, 2001). During research this condition was not found. Skeletonema sp domination was particularly caused by euryhaline characteristic, which is can grow in temperature 
from $3-30^{\circ} \mathrm{C}$. This characteristic may cope the environment fluctuation (Basmi, 1999).

\subsection{The Relation between Phytoplankton Composition with Pearl Farming Location}

Phytoplankton play key role for pearl farming. The density and composition of phytoplankton are some of the important factors that determine the farming location. As a primary producer in food chain, phytoplankton is used as an indicator for water prolificacy.

The result showed that the quantity of the phytoplankton found in Sekotong, was abundant. They were used as food source and help the oysters grow. Phytoplankton from Bacillariophyceae, and the a including is: Leptocylindricus sp., Thalassionema sp., Chaetoceros sp., Nitschia sp., Rhizosolenia sp., Bacteriastrum sp., and Asterionella japonica, generally used in pearl farming even since hatchery stage (Fukumuri et al., 2007). Furthermore, the composition of food source in oyster stomach (Pinctada fucata) was phytoplankton (78\%) and attached microalgal (22\%), respectively.

Another group of phytoplankton that can produce toxin were also found in area. The densities of Dinophyceae family that can produce oxidaic acid (toxin) were low. This group can be in rest stage by forming cyst and also can regrow in suitable environment (Gosling, 2003). This family have the most toxic derivate among other toxic phytoplankton group (Hamzah, 2003). The density of group in pearl farming area was 1189 cell/L blooming stage is 5000 cell/L (Basmi, 1999).

Based on the description above, the area is suitable for pearl farming. The water condition can be measured from phytoplankton composition. The composition of phytoplankton will low if the water is polluted or the nutrient is low (Handayani, 2008).

\subsection{Physical and Chemical}

The water temperature in both location in Sekotong were $28^{\circ} \mathrm{C}-29^{\circ} \mathrm{C}$. Accord- ing to ministerial decision from Environmental Ministry the range is suitable for pearl oyster life. The temperature in tropical region is $26-30^{\circ} \mathrm{C}(16)$. Most of the marine organism in tropic region can tolerate until $20-30^{\circ} \mathrm{C}$ (Haumau, 2005).

The salinity in sampling area is $30 \%$. According to water standard quality the Salinity is save for oyster. Subsequently, Agusta (2012) explained that the range of salinity for pearl oyster is $15-35 \%$.

Acidity has effect on growth of marine organism. The water with high acidity can cause mortality (Haumau, 2005). The acidity number from sampling locations are 8,09 (location 1) and 7,67 (location 2). According to Augusta (2012) the acidity range in Indonesia's water is 6,0 to 8,5 while the optimum acidity for aquaculture is 7 8,5 .

Average dissolved oxygen in locations are 4,3 ppm (location 1) and 6,3 (location 2). The standard quality of dissolved oxygen is vary (Hendrawati et al., 2007) but the minimum range is between $4-5 \mathrm{ppm}$. Another chemical quality that must be considered for pearl farming is nitrogen concentration. The nitrite form can bond with blood and become toxic to the organism. Nitrite concentration in both location were $0,01-$ $0,02 \mathrm{mg} / \mathrm{l}$.

Phosphate concentration in water can be as indicator for pollution. In nature, they usually in organophosphate or polyphosphate form. High phosphate concentration can be caused by eutrophication that can make the growth of phytoplankton exponentially. The optimum concentration for phytoplankton growth is $0,27-5,51 \mathrm{ppm}$ (Hendrawati et al., 2007). The phosphate concentration in both locations is in optimum condition for phytoplankton growth $(0,3-0,5 \mathrm{mg} / \mathrm{l}$.).

Ammonia concentration in location 1 was $0,018 \mathrm{mg} / \mathrm{l}$ (surface) and $0,21 \mathrm{mg} / \mathrm{l}(7$ $\mathrm{m}$ ); location 2 was $0,015 \mathrm{mg} / \mathrm{l}$ (surface) and $0,018 \mathrm{mg} / \mathrm{l}(7 \mathrm{~m})$. The ammonia in water is mostly from organism metabolism and organic waste decomposition by bacteria (Hen- 
drawati et al., 2007). The standard quality of ammonia in water is $0,3 \mathrm{mg} / \mathrm{l}$. this mean that the ammonia concentration in locations were suit for marine aquaculture including pearl farming.

\subsection{Water Quality in Sekotong and the Pearl Farming Production}

Phytoplankton composition in Sekotong consists of 24 species. Skeletonema sp., Chaetoceros sp., Thalassionema sp., and Pseudonitschia sp are phytoplankton species that used to feed pearl oyster. In Sekotong their density were above $10^{4}$ cell/l. The physical and chemical parameter of water in Sekotong is accordance with the ministerial decision of Lingkungan Hidup number $51 / 2004$.

The yield of pearl oyster farming in BBL is shown in Pic 2. The production was increasing in location 2 . The production fluctuation in location 1 was particularly caused by biofouling / attached the organism.

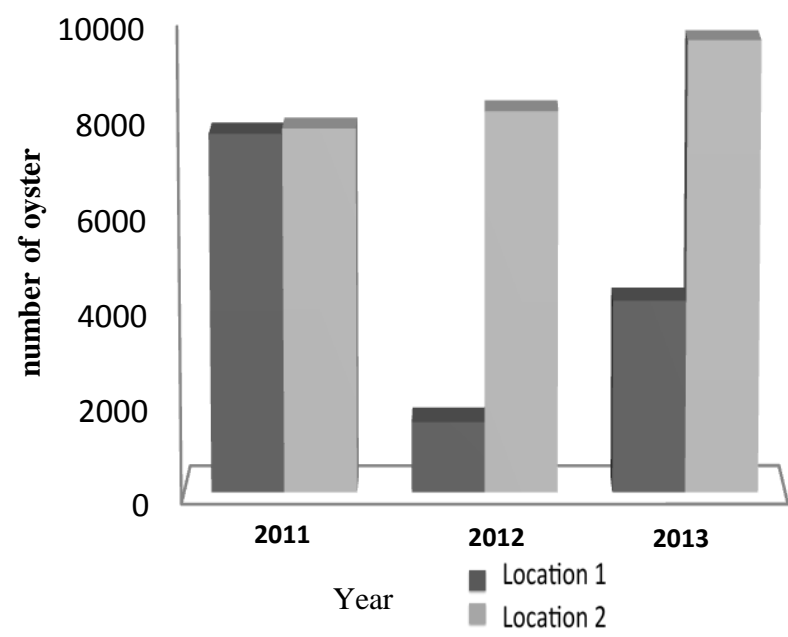

Picture 1. Production of pearl oyster in Balai Benih Laut (BBL).

The feeding competition between oyster and biofouling such as barnacle (Isnantyo and Kuniastuty, 1995) may affect the growth of oyster.

\section{SUMMARY}

Bacillariophyceae was class of phytoplankton that dominant in Sekotong water. Most of the phytoplankton from this class was used to feed the oyster farming. Harmful phytoplankton from Dinophyceae class was found but in a small amount. The physical and chemical characteristic in water showed that the nutrition is adequate for phytoplankton growth and it was required for oyster viability.

\section{ACKNOWLEDGEMENTS}

We would like to thank the Directors of Marine Aquaculture Institute, Lombok and Indonesian Sciences Institute, Lombok who provided opportunities for us to conduct this study.

\section{REFERENCES}

Anggoro, S. 2004. Pengelolaan kawasan konservasi laut daerah MSDP. Universitas Diponegoro Press. Semarang. 245hlm.

Astuti, L.P. and H. Satria. 2009. Kelimpahan dan komposisi fitoplankton di danau Sentani, Papua. J. Limnotek, 16: 88-98.

Agusta, C.P. 2012. Model pengembangan minapolitan berbasis budidaya laut Kabupaten Kupang. Desertasi. IPB. $124 \mathrm{hlm}$.

Basmi, H.J. 1999. Planktonologi: bioekologi plankton algae. Institut Pertanian Bogor. Bogor. 157hlm.

Dunphy, B.J., J.A. Hall, A.G. Jeffs, and R.M.G. Wells. 2006. Selective particle feeding by the Chilean oyster, ostrea chilensis, implications for nursery culture and broodstockconditioning. Aquaculture, 261(2):594-602.

Dwiponggo, A. 1976. Mutiar. Lembaga penelitian perikanan laut. Jakarta. 57hlm. 
Effendi, H. 2003. Telaah kualitas air bagi pengelolaan sumberdaya dan lingkungan perairan. Kanisius Yogyakarta. $157 \mathrm{hlm}$.

Efrizal, T. 2001. Kualitas perairan di sekitar lokasi penambangan pasir desa Pongkar Kabupaten Karimun, Berkala Perikanan Terubuk, 74(28):50-58.

Fernandez, E.M. and H.A. Salmon. 2004. Ingestion and digestion of 10 spcies of microalgae by winged pearl oyster Pteria sterna (Gould, 1851) larvae. Aquaculture, 230:417-423.

Fernandez., E.M., H.A. Salmon, and P.C. Southgate. 2006. The nutritional value of seven species of tropical microalgae for black-lip pearl oyster (Pinctada margaritifera, L.) larvae. Aquaculture, 257:491-503.

Fukumori, K., M. Oi, H. Doi, D. Takahashi, N. Okuda, T.W. Miller, M. Kuwae, H. Miyasaka, M.G. Kato, Y. Koizumi, K. Omori, and H. Takeoka. 2007. Food sources of the pearl oyster in coastal ecosystem of Japan: evidence from diet and stable isotope analysis. Aquaculture, 79:45-50.

Gosling E. 2003. Bivalve Molluscs. Britain : MPG Books Ltd. 132p.

Hamzah MA. 2008. Hubungan kuantitatif antara fitoplankton dengan zooplankton di perairan Waduk Krenceng Cilegon-Banten. Banten. 123hlm.
Haumau, S. 2005. Distribusi spatial fitoplankton di perairan Teluk Haria Saparua, Maluku Tengah. J. of Marine Sciences, 10(3):126-136.

Maria, H. 2002. The basic methods of pearl farming: a layman's manual, CTSA publication. 389p.

Hendrawati, T., H. Prihadi, dan N.N. Rohmah. 2007. Analisis kadar phosfat dan N-nitrogen (amonia, nitrat, nitrit) pada tambak air payau akibat rembesan lumpur lapindo di Sidoarjo, Jawa Timur. Universitas Islam Negeri Syarif Hidayatullah. Jakarta. 87hlm.

Matthiessen, G.C. 2001. Oyster Culture, Blackwell Science Ltd. 125p.

Powell, E.N., E.A. Bochenek, J.M. Klinck, and E.E. Hofmann. 2002. Influence infood quality on the growth and development of Crassostrea gigas larvae: a modelling approach. Aquaculture, 201:89-117.

Powell, E.N., E.A. Bochenek, J.M. Klinck, and E.E. Hofmann. 2004. Influence of short term variations in food on survival of Crassostrea gigas lar- vae: a modelling study. J. Marine Science, 62:117-152.

$\begin{array}{ll}\text { Dierima } & : 29 \text { April } 2014 \\ \text { Direview } & : 5 \text { Mei } 2014 \\ \text { Disetujui } & : 19 \text { Maret } 2015\end{array}$

